\title{
3 径間連続マルチケーブル斜張橋の部材断面力算定法の提案

\author{
A PROPOSAL OF EVALUATING METHOD OF THE SECTIONAL FORCES \\ OF THE THREE SPAN CONTINUOUS CABLE-STAYED GIRDER BRIDGE \\ WITH MULTIPLE CABLES
}

\author{
長井 正 嗣*・赤尾 宏**・佐野信一郎***・井 澤 \\ 衞 \\ By Masatsugu NAGAI, Hiroshi AKAO, Shinichiro SANO and Mamoru IZAWA
}

\begin{abstract}
This paper presents equations and figures for evaluating the sectional forces of each members of the cable-stayed girder bridges with multiple cables. These results are useful not only for the understanding of the static behavior of the bridge but also available for the check of the results obtained by the electric computer which is inevitable in the design stage. Especially, BEF analogy is used for the evaluation of the sectional forces and a new parameter concerning the rigidity ratio between the bending stiffness of the girder and axial stiffness of the cables is presented.
\end{abstract}

\section{1. まえがき}

周知の亡おり，斜張橋は高次の不静定構造物であり， その構造解析に当たっては，電子計算機の利用が必要不 可欠である。 また，斜張橋が戦後急速に発展したのは， 電子計算機の発達に負う所が大きいこともよく知られて いる.しかしながら，斜張橋の基本設計に当たって，逐 一大型計算機を駆使して解析することは必ずしも得策で はなく, 各部材の断面力を事前に精度よく推定しておく ことは基本計画上きわめて有益であると考える．あわせ て，これらの断面力を理論的に究明しておくことが，斜 張橋の力学性状を明確にする上でも有益であると考え る.

さて, 斜張橋の断面力のうち, 主析 · 主塔の軸力につい ては比較的精度のよい算定法が与えられているものの ${ }^{11}$, 主桁とケーブルの剛比に密接に関連する活荷重による主 桁曲げモーメントおよびケーブル張力については, その 推定が困難とされている.さらに，主桁とケーブルの剛

* 正会員 工博 川崎重工業(株) 橋梁設計部第 1 設計課 係長 ( 136 江東区南砂 2-4-25)

** 正会員 川崎重工業(株) 橋梁設計部部長 (同上)

*** 正会員 川崎重工業(株) 橋梁設計部第 1 設計課課長 (同上)

**** 正会員 工修 川崎重工業(株) 橋梁設計部第 1 設計課 (同上)
比に関するパラメーターの定義についても不明確な点が あるのが実情である.

以上より，本文では，今後ますます大型化する斜張橋 において主流になると予想されるマルチケーブルタイプ を対象に, 各部材の断面力の算定法を示すとともに,ケー ブルと主桁の剛比選定に関する検討を行い基本計画上の 一資料を提示することとした。すなわち，まず，主桁・ 主塔の軸力および端支点反力算定法を示し，次に主桁曲 げモーメント，ケーブル張力算定法を示す．後者につい ては, マルチケーブル斜張橋を弾性床上のはりに置き換 えたモデルにより検討を行う。さらに，弾性床上のはり モデルを考える場合，ケーブルと主桁の剛比が密接に関 連することから，これらについて新しいパラメーターを 定義して検討を行うこととする.

\section{2. 主桁・主塔の軸力および反カ}

主桁, 主塔の軸力は, ケーブルを介して導入されるこ とから,まず，ケーブル張力と荷重の関係を求める ${ }^{11}$. 両者の関係は, Fig. 1 を参照して

$$
\left.\begin{array}{l}
T \sin \alpha=q d x \\
T \cos \alpha=d H
\end{array}\right\}
$$
( 1$)_{a, b}$

と与えられる.ここに， $T$ はケーブル張力, $d H$ は水平 分力の増分, $\alpha$ はケーブル亡析のなす角度, $q$ は外力で 
ある。

式（1）より

$$
d H=\frac{\cos \alpha}{\sin \alpha} q d x=\frac{q}{h} x d x
$$

となる、ここに， $h$ は塔高さ（桁上）である.

式 $(2)$ より, $q, h$ を一定とすれば， $x$ 位置での水 平張力は,

$$
H=\frac{q}{h} \int x d x
$$

と与えられる.

次に，側径間最上段ケーブルの張力を考える．まず， 主析死荷重 $W_{d}$ による水平張力は, 中央径間と側径間の 死荷重のバランス差により生じることから，

$$
\begin{aligned}
H_{c} & =\frac{W_{d}}{h} \int_{0}^{l_{c} / 2} x d x-\frac{W_{d}}{h} \int_{0}^{l_{s}} x d x \\
& =\frac{W_{d} l_{c}^{2}}{8 h}\left\{1-4\left(\frac{l_{s}}{l_{c}}\right)^{2}\right\} \ldots \ldots \ldots \ldots \ldots . .
\end{aligned}
$$

となり，したがって，張力 $T_{D}^{u}$ は，

$$
T_{D}^{u}=H_{c} / \cos \phi \text {. }
$$

と定義できる.ここに， $\phi$ は最上段ケーブルと桁のなす 角度で, 死荷重強度は全径間一定とする.

次に, 活荷重による最大, 最小張力を求める. 中央径 間満載時および側径間満載時, 最上段ヶーブルのみで抵 抗するとして (Fig. 2 参照),

$$
\left.\begin{array}{c}
T_{\rho, \max }^{u}=\frac{p_{c} l_{c}{ }^{2}}{8 h} / \cos \phi \\
T_{\rho, \min }^{u}=\frac{p_{s} l_{s}{ }^{2}}{2 h} / \cos \phi
\end{array}\right\}
$$

となる.ここに, $T_{p, \max }^{u}, T_{p, \min }^{u}$ はそれぞれ側径間最上 段ケーブルの活荷重最大および最小張力， $p_{c} ， p_{s}$ はそ れぞれ中央径間および側径間の活荷重強度である.. $p_{c}$ ， $p_{s}$ の差は支間長の差に起因する活荷重強度および衝撃

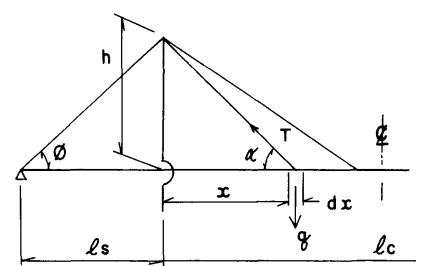

Fig. 1 Equilibrium between Cable Tension Force and External Load.

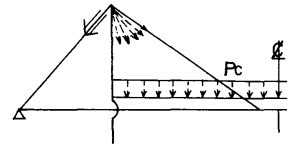

(a) Max. Tension

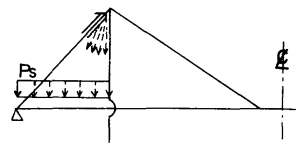

(b) Min. Tension
Fig. 2 Loading for Max. and Min. Tension Force of the highest Cable in a Side Span.
係数の差によるもので，長大橋になるほど，その差は小 さくなると考えてよい. また, 集中荷重については, 長 大橋ほどその影響が小さいことから無視している。ただ し, 以後に説明するケーブル単独の張力および主析曲げ モーメントの算定には考慮する.

主析の最大軸力は， $p_{c} \cong p_{s} \cong p$ として，式（ 3 ）より，

$$
N_{G, \max }=\frac{q}{h} \int_{0}^{l_{c} / 2} x d x=\frac{q l_{c}^{2}}{8 h}
$$

となる.ここに， $q=W_{d}+p$ で，ケーブルが塔頂部で分 散されて定着される場合は， $h$ として Fig. 5 に示す $\bar{h}$ を用いる。

次に, 主塔の最大軸力は, 中央径間部の荷重を支持す ることから，

$$
N_{T, \max }=q l_{c}
$$

となり，側径間と中央径間の支間長比にかかわりなく， 中央径間長のみに依存する，ただし，塔の自重および析 反力の影響は別途考慮するものとする.

以上を整理すると，主桁，主塔の軸力分布は Fig. 3 に 示すとおりとなる.なお，図中の $\alpha_{2}, \alpha_{4}$ は, 式 (3) より, 主析軸力分布が放物線分布になることを考慮して 得られたものである.

次に，反力について考える．斜張橋の反力のうち，側 径間端支点の上揚力の処理が設計上重要な問題になるこ とから，この上揚力の算定法を示す. 式 (5), (6)a より,

$$
\begin{aligned}
R^{u} & =\left(T_{D}^{u}+T_{p, \max }^{u}\right) \sin \phi \\
& =\left[\frac{W_{d} l_{c}^{2}}{8 h}\left\{1-4\left(\frac{l_{s}}{l_{c}}\right)^{2}\right\}+\frac{p l_{c}{ }^{2}}{8 h}\right] \tan \phi
\end{aligned}
$$

と与えられる.ここに， $R^{u}$ は上揚力，また， $h$ の取り

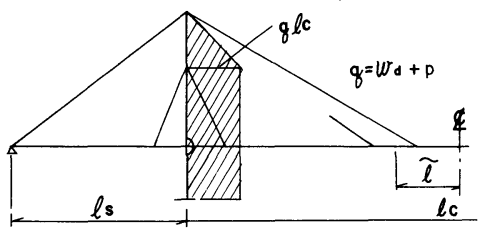

(a) Tower

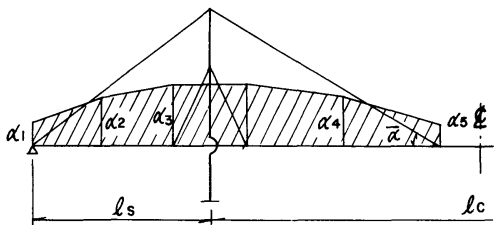

$$
\begin{array}{ll}
\alpha_{1}=\frac{w_{d} l_{c}^{2}}{8 h}\left\{1-4\left(\frac{l_{s}}{l_{c}}\right)^{2}\right\}+\frac{p l_{c}^{2}}{8 h} \\
\alpha_{3}=\frac{q \ell_{c}^{2}}{8 h} \quad \alpha_{2}=\left(\alpha_{1}+3 \alpha_{3}\right) / 4 \\
\alpha_{5}=q \widetilde{l} / \tan \bar{\alpha} & \alpha_{4}=\left(\alpha_{5}+3 \alpha_{3}\right) / 4
\end{array}
$$

(b) Main Girder

Fig. 3 Axial Forces of the Tower and the Main Girder. 
扱いは式 ( 7 ) と同様である.

式（9）より, 支間長比 $\left(=l_{c} / l_{s}\right)$ が大きくなるほ ビ上揚力が大きくなることがわかる.

ところで, 支間長比が小さくなる場合, 式（9）によ れば，死荷重による上揚力が 0 に近づくが，実用上の観 点からは式 (9) に代わって

$$
R^{u}=\left(\frac{W_{d} \tilde{l}}{\tan \tilde{\alpha}}+\frac{p l_{c}{ }^{2}}{8 h}\right) \tan \phi
$$

を用いればよい.ここに， $\bar{\alpha}, \tilde{l}$ はFig. 3 に定義されて いるものである. 支間長比が小さくなる場合, 式 (9) または式（10）のうち大きい方の值を用いればよい.

\section{3. 塔曲げモーメント}

死荷重状態での曲げモーメントは既知であるとして, 活荷重による塔頂部最大曲げモーメントを求める. 中央 径間に活荷重が満載された状態での塔頂近傍のケーブル 水平張力分布はFig. 4 (a) のとおりと予想される.こ れを,Fig. 4(b) の分布に置き換える.さらに, 構造 モデルとしては，Fig. 5 に示す塔頂ばねを有する片持ち ばりモデルを考える

ここで，塔頂ばねについて考える，中央径間に活荷重 が満載された状態で, 側径間最上段ケーブルの伸びによ り, 塔頂は橋軸方向に,

$$
\delta_{H}=\frac{l_{s}^{2}+h^{2}}{l_{s}}\left(\frac{\sigma}{E_{c}}\right)
$$

変位する.ここに, $E_{c}$ はケーブルのヤング率, $\sigma$ はケー ブルの発生応力である.

橋軸方向の変位が定義できれば, Fig. 5 に示す不静定 力 $R_{T}$ は,

$$
R_{T}=\frac{q_{h} h^{\prime}}{8} \xi\left(8-6 \xi+\xi^{3}\right)-3 \frac{l_{s}{ }^{2}+h^{2}}{l_{S} h^{\prime 3}} \sigma I_{T}
$$

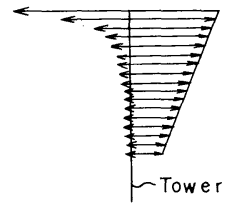

(a) Actual

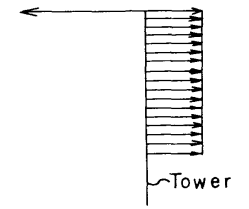

(b) Idealized
Fig. 4 Cable Tension Force near the Tower Top.

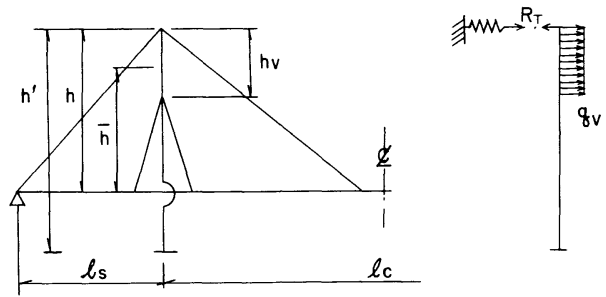

Fig. 5 Notation for Tower Moment.
となる。ここに，

$$
\left.\begin{array}{l}
q_{h}=\frac{p l_{c}{ }^{2}}{8 \bar{h}} / h_{v} \\
\xi=h_{V} / h^{\prime}
\end{array}\right\}
$$

また， $I_{T}$ は塔の断面二次モーメントである.

式 (12) の右辺第 2 項に側径間長の影響が考慮される ことになるが, 塔高さ $h^{\prime}$ が大きいほどこの効果は小さ くなる. したがって, 基本計画上の概略値としては, 式 (12) の右辺第 2 項は無視してよいと考える.

不静定力 $R$ が求まれば, 塔の最大曲げモーメントは,

$M_{\max }=R^{2} /\left(2 q_{h}\right)$

となる。

以上の精度については, のちほど数值計算例で報告す る.

\section{4. 主林最大曲げモーメントとケーブル張力}

ここでは，活荷重による主桁曲げモーメントおよび ケーブル張力の算定法を検討する．死荷重による曲げ モーメントは, ケーブルプレストレス量次第で大幅に変 動し，また，その決定法は設計者の判断に委ねられてい る.そこで, 本文では活荷重による上記断面力を取り扱 うこととした.

さて, マルチケーブル斜張橋の場合, ケーブルが比較 的密に配置されていることに着目し, 主析を弾性床上の はりとみなして検討を行う. 弾性㦿モデルのばね定数算 定法, 主枌断面二次モーメントの選定についてはのちほ ビ説明することとして，ここでは，それらが既知である として検討を行う.

無限弾性床上のはりに集中荷重 $P_{0}$ が作用した場合 (Fig. 6) の解として, 主桁曲げモーメント分析は,

$$
M=\frac{P_{0}}{4 \beta} e^{-\beta x}(\cos \beta x-\sin \beta x) \text {. }
$$

と与えられる.ここに，

$$
\beta=\sqrt[4]{\frac{k}{4 E_{G} I_{G}}}
$$

$k$ は弾性床のばね定数, $E_{G}, I_{G}$ はそれぞれ主析のヤン グ率および断面二次モーメントである.

次に，図中の $x_{0}$ は式 $(15)$ の右辺を 0 とおいて, $x_{0}=\pi / 4 \beta$

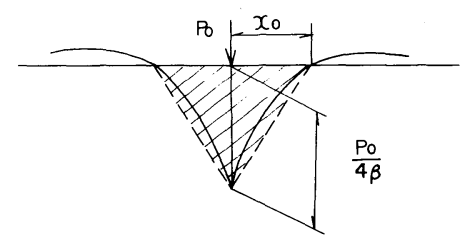

Fig. 6 Moment Distribution of the Girder on Elastic Foundation under Concentrated Load. 
となる.さらに, Fig. 6 の斜線部の面積 $(\bar{A})$ は分布形 状を三角形分布と仮定すれば,

$$
\bar{A}=\frac{1}{4 \beta} x_{0}=\frac{\pi}{16 \beta^{2}}
$$

となる.

これより, 分布荷重を $p$, 集中荷重を $P$ とすれば, 主桁の曲げモーメントは,

$$
M=\frac{p \pi}{16 \beta^{2}}+\frac{P}{4 \beta}
$$

と与えられる.ただし， $p, P$ には衝撃係数を含むもの とする.

ところで, 斜張橋の活荷重曲げモーメントのうち, 側 径間端支点近傍には大きな曲げモーメントが発生する。

側径間端支点近傍の曲げモーメント影響線正領域は側径 間全長にわたることから

$$
\begin{aligned}
M_{s} & =\frac{1}{4 \beta} \cdot \frac{p_{s} l_{s}}{2}+\frac{P_{s}}{4 \beta} \\
& =\frac{p_{s} l_{s}}{8 \beta}+\frac{P_{s}}{4 \beta} \ldots \ldots . . .
\end{aligned}
$$

と定義する.ここに，添字 $s$ は側径間の値を意味する.

次に, ケーブル張力について検討を行う. Fig. 6 に示 す荷重状態に対するたわみ分布は，

$$
\delta(x)=\frac{P_{0} \beta}{2 k} e^{-\beta x}(\cos \beta x+\sin \beta x)
$$

と与えられる21. したがって, 反力分布は,

$$
r(x)=k \delta(x)=\frac{P_{0} \beta}{2} e^{-\beta x}(\cos \beta x+\sin \beta x) .
$$

となる。

まず，集中荷重によるケーブル張力の鉛直成分を求め る. ケーブル位置両側の吊り点間隔の半分長で式 (22) を積分するが，隣接ケーブル吊り点間隔の和の半分を $L_{C D}$ とすれば,

$$
\begin{aligned}
R_{c} & =2 \int_{0}^{L c D / 2} r(x) d x \\
& =P_{0}\left(1-\cos \frac{\beta L_{c D}}{2} / e^{\frac{\beta L c D}{2}}\right) .
\end{aligned}
$$

となる．ここに， $R_{c}$ は集中荷重 $P_{0}$ に対するケーブル 張力の鉛直成分である ${ }^{\sharp 1)}$. いま, $\beta=0$ (ケーブル剛度 $=0 ）$ とすれば， $R_{c}=0$ となり， $\beta=\infty （$ 析の剛度 $=0 ）$ のとき, $R_{c}=P_{0}$ となる.

次に，等分布荷重によるケーブル張力の鉛直成分を求 める. 式 (22) は, $P_{0}=1$ とすれば, ケーブル張力鉛直 成分の影響線を表わしている. $r(x)=0$ なる $x_{u}$ を求め ると,

注 1) 文献1）では, 式 (23),（25）に対応する式として,

$$
R_{u}=p L_{c D}, R_{c}=\frac{P_{0} L_{c D}}{30 d}
$$

が与えられている. 前者は直観的に得られたものと考えられ， 後者については誘導過程が不明確である.ここに, $d$ は主析高 さである.

$$
x_{u}=3 \pi / 4 \beta \text {. }
$$

となる。これより, 影響線を直線近似すれば,

$$
R_{u}=p\left(1-\cos \frac{\beta L_{c D}}{2} / e^{\frac{\beta L c 0}{2}}\right) \frac{3 \pi}{4 \beta} .
$$

を得る.ここに， $R_{u}$ は等分布荷重 $p$ によるケーブル張 力の鉛直成分である. $R_{u}, R_{c}$ より，ケーブルの傾斜角 を考慮すればケーブル張力が求まることになる.

$$
\begin{aligned}
& \text { ところで, 式 }(25) \text { は } \\
& R_{u} / L_{c D}=\frac{3 \pi}{8} p\left(1-\cos \frac{\beta L_{c D}}{2} / e^{\frac{\beta L C D}{2}}\right) / \frac{\beta L_{c D}}{2}
\end{aligned}
$$

と表わせ, $\beta L_{c D} / 2$ を変数とみなして, $\beta L_{c D} / 2 \rightarrow 0$ とす れば

$$
R_{u}=\frac{3 \pi}{8} p L_{c D}=1.178 p L_{c D}
$$

に収束する．6. で示すとおり，実橋の $\beta$ が比較的小さ いこともあって, 設計上は安全側の考えから,

$$
R_{u}=1.2 p L_{c D}
$$

と定義する. すなわち，直観的に $R_{u}=p L_{c D}$ と考えられ ていたのに対し, 設計張力の鉛直成分は, 多少安全側で あるが，20\% 程度大きい値になる。

次に, ケーブルの分布荷重による張力と, 集中荷重に よる張力の比を考える. 式 (23)，（25）の比をとると，

$$
R_{\mathrm{c}} / R_{u}=\frac{P}{p} \frac{4 \beta}{3 \pi}\left(P=P_{0}\right)
$$

さらに, 式 (27) を代入すると,

$$
R_{c}=\frac{P \beta}{2} L_{c D}
$$

を得る.これより, 活荷重によるケーブル張力の鉛直成 分 $R$ は, 近似的に,

$$
R=\left(1.2 p+\frac{P \beta}{2}\right) L_{c D}
$$

と表わせる.

さて, 式 (29) について, 道路橋示方書 ${ }^{3)}$ の荷重強度 加, 分布荷重 $p=300 \mathrm{~kg} / \mathrm{m}^{2}$ (支間長 $130 \mathrm{~m}$ 以上とし て), 線荷重 $P=5 \mathrm{t} / \mathrm{m}$ とし, かつ衝撃係数を共通とす れば,

$$
R_{c} / R_{u}=7 \beta
$$

となる.これより，ケーブル張力の鈶直成分 $R$ は，

$$
R=(1+7 \beta) R_{u}
$$

とも定義できる.

\section{5. ケーブルのばね定数}

4. では, ケーブルのばね定数および枌の断面二次モー メントが既知であるとして検討を行った.ここでは，そ のうち, ケーブルばね定数の評価法について検討を加え ることとする.

斜張橋の最大たわみは，ケーブルの伸びに支配される 
として求めた式より,

$$
\begin{aligned}
\delta_{A} & =\left(\frac{\sigma}{E_{c}}\right)_{s} \frac{L_{s} L_{A}}{h}+\left(\frac{\sigma}{E_{c}}\right) \frac{L_{A}{ }^{2}}{h} \\
& =\frac{\alpha \bar{\beta} \sigma_{a}}{E_{c}} \frac{L_{s} L_{A}}{h}+\frac{1.1 \omega}{1+1.3 \omega} \frac{\bar{\beta} \sigma_{a}}{E_{c}} \frac{L_{A}{ }^{2}}{h} \\
\delta_{\max } & =\frac{l_{c}}{2 l_{c}^{\prime}} \delta_{A} \ldots \ldots \ldots \ldots \ldots \ldots \ldots \ldots \ldots \ldots \ldots \ldots \ldots \ldots
\end{aligned}
$$

と与えられている ${ }^{4)}$.ここに， $\delta_{A}$ は中央径間最上段ケ一 ブル位置のたわみ, $\left(\sigma / E_{c}\right)_{s}, L_{s}$ はそれぞれ側径間最上 段ケーブルのひずみと長さ， $\left(\sigma / E_{c}\right)_{A}, L_{A}$ はそれぞれ中 央径間最上段ケーブルのひずみと長さ， $\sigma_{a}$ はケーブル の許容応力, $\tilde{\beta}(<1.0)$ はケーブルの許容応力に対して どの程度の余裕で設計するかに依存する值で設計者の判 断に委ねられる值， $\alpha(<1.0)$ は側径間最上段ケーブル の全張力のうち活荷重の占める割合で Fig. $7^{4)}$ に示すも のである，図中，実線は活荷重が中央径間に満載された ケース, 破線は活荷重が側径間に満載されたケースの值 である. また， $l_{c}^{\prime}$ は塔位置支点から中央径間最上段ケー ブル取り付け位置までの水平長, 係数 $1.1 \omega /(1+1.3 \omega)$ は, 中央径間最上段ケーブル全張力のうち活荷重の占め る割合を定義するもので， $\omega=p / W_{d}$ である.

なお，式（35）が十分な精度を有することは，文献

4) で確認されている.

次に，支間中央部および側径間端支点近傍のケーブル ばね定数算定法として, 無限弾性床上のはりのたわみに 着目し, 式 (34),（35）で求めたたわみとの等価性を利 用した考えを採用する。

無限弾性床上のはりのたわみに着目すると, 集中荷重 $P$ に対して, 荷重直下で,

$$
\delta_{P}=\frac{P \beta}{2 k}
$$

また, 分布荷重 (載荷幅 $\left.l_{c}\right) p$ に対して, 載荷中央で

$$
\delta_{p}=\frac{p}{k}\left(1-e^{-\frac{\beta l_{c}}{2}} \cos \frac{\beta l_{c}}{2}\right)
$$

と与えられる．ところで，無限弾性床上のはりの理論を 適用する範囲が $\beta l_{c}>\pi$ であることから，一般に式 (37)

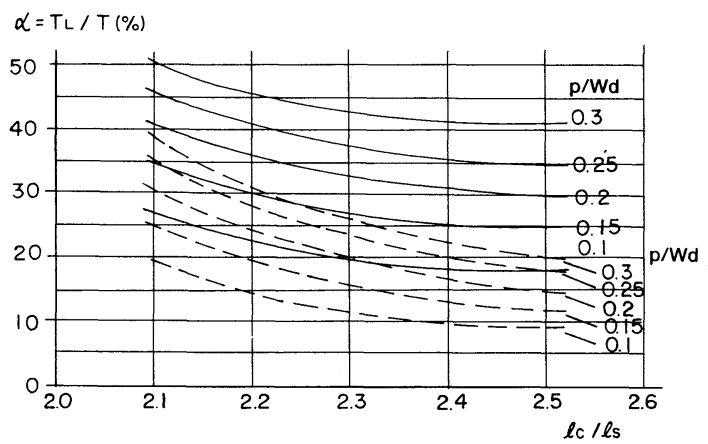

Fig. 7 Estimation of $\alpha$ Value.
の右辺第 2 項の影響は小さい. そこで，

$$
\delta_{p}=\frac{p}{k}
$$

と近似する.したがって，

$$
\begin{aligned}
\delta_{\max } & =\delta_{p}+\delta_{P} \\
& =\frac{p}{k}+\frac{P \beta}{2 k}=\frac{1}{k}\left(p+\frac{P \beta}{2}\right) .
\end{aligned}
$$

より，

$$
k=\frac{1}{\delta_{\max }}\left(p+\frac{P \beta}{2}\right)
$$

と定義できる.

側径間のばね定数評価に当たっては, 式 (34) の $L_{A}$ として， $L_{s}$ を考え， $\alpha$ としては Fig. 7 の破線を用いて たわみ $\delta$ を求める. そして, 式 $(40)$ の $\delta_{\max }$ に代入し て $k$ 值を求める.

ところで，式 (40) には $\beta$ が含まれており，このま までは不都合である。この取り扱いについてはのちほど 説明を加えるが，桁の断面二次モーメントが既知の場合 には， $\beta$ を仮定（たとえば， $\beta=10 / l_{c}$ ) して収束計算を 行えば数回の繰り返しで収束值が得られる.

\section{6. 主桁とケーブルの剛比に関する考察}

主析とケーブルの風比に関するパラメーターとして, $\gamma_{1}=\frac{E_{c} A_{c}}{E_{G} I_{G}} l_{T}^{2}$

が提案されている ${ }^{5)}$.ここに， $l_{T}$ は桁の全長である.こ のパラメーターは物理的意味が不明確であるとして，

$$
\gamma_{2}=\frac{E_{c} \Sigma\left(A_{c i} / l_{i}\right) \sin ^{2} \alpha_{i}}{E_{G} I_{G}} l_{T}^{3}
$$

が提案されている ${ }^{6)}$. ここに， $A_{c i}, l_{i}, \alpha_{i}$ はそれぞれ $i$ 番目ケーブルの断面積, 長さおよび桁よのなす角度で, $\sum$ は総和記号である.

$\gamma_{2}$ は離散的に配置されたばね上のはりの無次元パラ メーターに対応し，物理的意味はより明確になっている ものの, 主塔の変形が考慮されておらず，ケーブルのば ね定数が正確には評価されていない欠点を有する.

ところで, 著者らは弾性床上のはりの問題 (BEF ア ナロジー）を斜張橋の構造解析に適用した。それによれ ば,

$$
\gamma_{3}=\beta \bar{l}
$$

が無次元パラメーターとして定義できる.ここに，厌は 長さの単位を有する物理量である.ささ，本文では， $\bar{l}$ として中央支間長 $l_{c}$ を選定し, 新しいパラメーターと して,

$$
\gamma=\beta l_{c}=\sqrt[4]{\frac{k}{4 E_{G} I_{G}}} \cdot l_{c}
$$

を定義する．ここに， $k$ は式 $(40)$ で定義されるもので， 支間中央の $k$ 值を代表とする. 
式 (44) のパラメーターを用いて, わが国の 3 径間連 続斜張橋の実績調查を行った結果および 7. の数值計算 例で示す支間 $600 \mathrm{~m}$ のモデルについて計算した結果を Fig. 8 に示す. 図中には，参考のため少数段ケーブルを 有する斜張橋の結果も含まれている.

これより, 支間 $200 \mathrm{~m} \sim 300 \mathrm{~m}$ の斜張橋の $\beta l_{c}$ は $4 \sim 5$ で, このクラスの斜張橋でも, 中央径間について無限弾 性床上のはりモデルの適用は妥当であることがわかる. また， $\beta$ 値については，支間 $300 \mathrm{~m}$ 以上では 0.016 以下 となっている.

ところで, 式 (34) で中央径間最上段ケーブルの張力 のうち活荷重の占める割合を $1.1 \omega /(1+1.3 \omega)$ と定義 したが, 式 (33) に $\beta=0.016$ を代入すると,

$R=1.112 R_{u}$

となり，これより，線荷重の影響を分布荷重の約 $10 \%$ 増として評価したものである．さらに，分布荷重による 設計張力の鉛直成分は $1.2 p L_{c D}$ であることから, 分母 の係数として, $1.1 \times 1.2 \cong 1.3$ を考えている.

次に, $\beta l_{c}$ をパラメーターとして, 中央径間主桁曲げ モーメントの収束状態を検討した，支間 $600 \mathrm{~m}$ のモデ ルを考え, 主桁断面二次モーメントを種々変化させて解 析した結果を Fig. 9 に示す. 図中, 縦軸は曲げモーメン トを $M_{\infty}$ (ばねのない場合の曲げモーメント) で無次元 化したものである.

これより, 分布荷重に対して, $\beta l_{c}=10$, 集中荷重に 対して $\beta l_{c}=20 \sim 30$ で収束していることがわかる. とこ ろで, $\beta l_{c}=10$ (Fig. 8 の破線) を収束値とみなし, こ れに対応する実橋の主桁断面二次モーメントを算定（た だし， $k$ は実橋の值を採用）すると, 現状の $1 / 10 \sim 1 /$ 30 程度となり，かなり小さい值になることがわかった． 明らかに, 斜張橋としては, 主桁の曲げ剛度をほとんど 0 に近づけて，輪荷重にのみ抵抗する軸力部材に置き換 えることを意味しており， $\beta l_{c}=10$ が 1 つの目安になる と考えられる.しかしながら，このように小さい主桁断 面二次モーメントの採用については, 主标の座屈安定性 等解明すべき問題が多い，そこで，主析の曲げ剛性を設

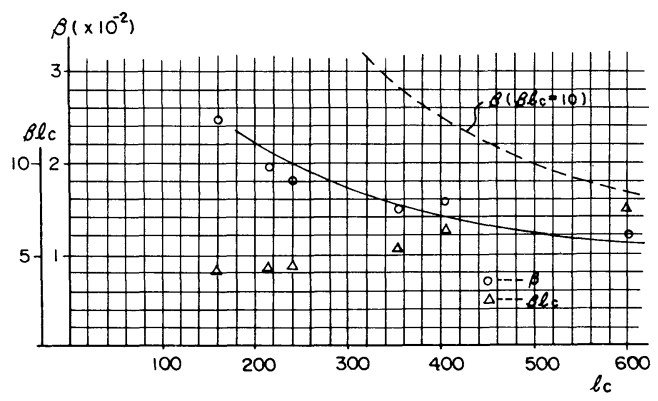

Fig. $8 \beta$ and $\beta l_{c}$ values.

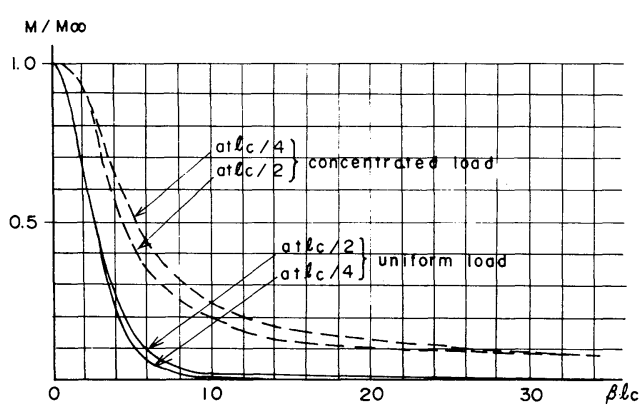

Fig. 9 Convergency of Bending Moment.

定する $\beta$ の初期値としては, 実績と $600 \mathrm{~m}$ モデルの計 算結果に基づいた Fig. 8 の実線の值を利用することを提 案する.

さて, 以上のとおり, 主枌断面二次モーメントの初期 值が設定され, さらに概略の断面力が得られれば, 仮定 した $I_{G}$ が，ほぼ妥当であるか検討可能となる. その際, 主析の断面二次モーメントを変更する必要が生じた場合 には, 以下の変動モーメント推定図の利用を提案する.

中央径間および側径間の曲げモーメントは式 (19) お よび式 (20) で与えられている. いま, 設定した $\beta$ 值 $(=$ $\left.\beta^{*}\right)$ で式 (19), (20) より曲げモーメントが与えられる. 次に, $I_{G}$ を変化させて, 新しい $\beta$ 値に対する曲げモ一 メントの変動を考える. 両者の比を考えると, 中央径間 に対して

$$
M_{c} / M_{c}^{*}=\frac{1}{\left(\beta / \beta^{*}\right)^{2}} \cdot \frac{1+(4 P / p \pi) \beta}{1+(4 P / p \pi) \beta^{*}}
$$

側径間に対して,

$$
M_{s} / M_{s}^{*}=\frac{1}{\left(\beta / \beta^{*}\right)}
$$

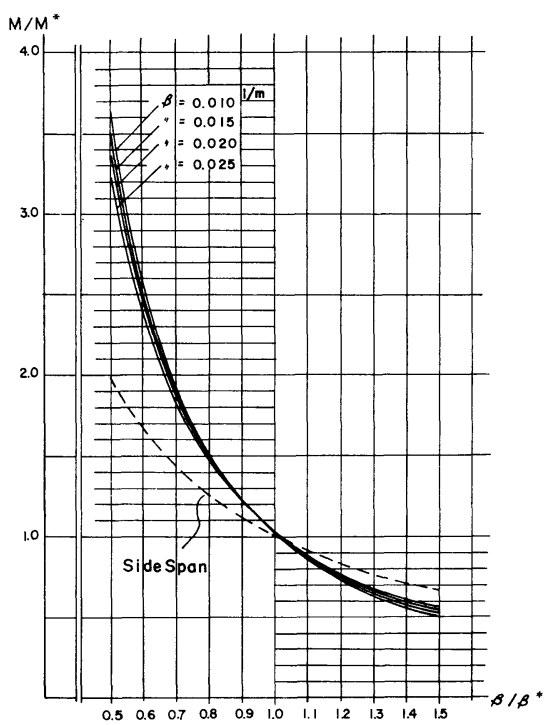

Fig. 10 Relationship between $M / M^{*}$ and $\beta / \beta^{*}$. 
Table 1 Comparison of $M / M^{*}$ value between proposed and calculated values.

\begin{tabular}{|c|c|c|c|c|c|c|c|}
\hline \multirow[b]{2}{*}{ I. $\left(m^{4}\right)$} & \multirow[b]{2}{*}{$\beta \times 10^{-2}$} & \multicolumn{3}{|c|}{ center span } & \multicolumn{3}{|c|}{ side span } \\
\hline & & (a) eq. (46) & (b) calculated & (a) $/$ (b) & (a) eq. (47) & (b) calculated & (a) $/$ (b) \\
\hline 0.4 & $\begin{array}{l}1.624 \\
(1.545) \\
\end{array}$ & $\begin{array}{c}0.63 \\
(0.68) \\
\end{array}$ & 0.68 & 0.93 & $\begin{array}{r}0.75 \\
(0.79) \\
\end{array}$ & $\begin{array}{l}0.68 \\
0.83 \\
\end{array}$ & $\begin{array}{l}1.10 \\
0.90 \\
\end{array}$ \\
\hline 0.8 & $\begin{array}{l}\text { 1. } 354 \\
\text { (1. } 330)\end{array}$ & $\begin{array}{c}0.84 \\
(0.86)\end{array}$ & 0.87 & 0.97 & $\begin{array}{c}0.90 \\
(0.92)\end{array}$ & $\begin{array}{l}0.88 \\
0.90\end{array}$ & $\begin{array}{l}1.02 \\
1.00\end{array}$ \\
\hline 2.4 & $\begin{array}{l}1.017 \\
(1.047)\end{array}$ & $\begin{array}{l}1.36 \\
(1.29)\end{array}$ & 1.30 & 1.05 & $\begin{array}{l}1.20 \\
(1.16)\end{array}$ & $\begin{array}{l}1.22 \\
1.16 \\
\end{array}$ & $\begin{array}{l}0.98 \\
1.03\end{array}$ \\
\hline 4.8 & $\begin{array}{c}0.085 \\
(0.090)\end{array}$ & $\begin{array}{l}1.85 \\
(1.67) \\
\end{array}$ & 1.71 & 1.08 & $\begin{array}{l}1.43 \\
\text { (1. } 35) \\
\end{array}$ & $\begin{array}{ll}\max . & 1.55 \\
\min . & 1.41 \\
\end{array}$ & $\begin{array}{l}0.92 \\
1.01\end{array}$ \\
\hline
\end{tabular}

$\beta^{*}=0.012181 / \mathrm{m}$ for $\mathrm{I} g=1.2 \mathrm{~m}$

() : using calculated $\delta$ max. for evaluation of $k$ value

と与えられる．ここに， $M_{c} ， M_{s}$ はそれぞれ $\beta$ 值での中 央径間および側径間曲げモーメント， $M_{c}^{*} ， M_{s}^{*}$ はそれ ぞれ， $\beta^{*}$ 値での曲げモーメントである. 式 (46)，(47) の結果を Fig. 10 に示す $\left(p=300 \mathrm{~kg} / \mathrm{cm}^{2}, P=5 \mathrm{t} / \mathrm{m}\right)$.

次に, 式 (46)，(47）の妥当性を検討するために，7. 数值計算例で示す, 支間 $240 \mathrm{~m}+600 \mathrm{~m}+240 \mathrm{~m}$ の斜張 橋の主析断面二次モーメントを変化させて比較した結果 を Table 1 に示す. $\beta$ 值としては, 主析たわみが断面二 次モーメントが変化しても変わらないとしたケース，断 面二次モ一メントの変化に伴うたわみ変化を考慮した 2 ケースの結果が与えられている. 後者を（）内数值で 示す. 算定式と電算結果の比（表中の $(a) /(b))$ は前者 との比である.

これより, 主析断面二次モーメントを 2 倍程度変化さ せて, 誤差は 2 3\%であり，4倍程度変化させて, 誤 差は 8〜 $10 \%$ となっており，実用上の観点からは十分 な精度を有していることがわかる.

\section{7. 数值計算例}

Fig. 11，12 に示す中央支間 $600 \mathrm{~m}$, 側径間長それぞ れ $240 \mathrm{~m}$ (Type A), $284 \mathrm{~m}$ (Type B) で, 塔高さ 170 $\mathrm{m}$ (桁上 $130 \mathrm{~m})$ の 3 径間連続マルチケーブル斜張橋に ついて，断面力算定式による值と計算値の比較を行った
結果を示す。断面性能および荷重強度は図中に示す.

（1）主桁軸力および曲げモーメント

Fig. 13，14 に主桁軸力および曲げモーメントの比較 結果を示す. 主桁軸力については Type A, Bともに, 最大軸力が約 $5 \%$ 程度小さめに評価されるが，ほぼ実 情よ゙おりの分布性状が得られることがわかる. 主析の曲 げモーメントについては，Type Bで，支間中央部約 $3 \%$ 程度小さめに評価されているが，実用上十分な精度 で評価できることがわかる.

主桁曲げモーメントについては，マルチケーブルの実 橋例として, 名港西大橋 $(\mathrm{M}$ 橋とよぶ), かもめ大橋 $(\mathrm{K}$ 橋 とよぶ）についても比較を行った． $\mathrm{M}$ 橋については, 本算定式は十分な精度を有していることが確認できた. $\mathrm{K}$ 橋については, 中央径間で約 $10 \%$ ，側径間で約 30 \%小さめに評価されることがわかった. 前者について は，中央径間部のケーブルで吊られていない区間長と中 央径間長の比 $\left(\alpha_{u}\right)$ が $1 / 5$ と大きくなっているためと 考えられる.ちなみに，この值は $\mathrm{M}$ 橋で $1 / 11$, 本計算 モデルで $1 / 15$ である. したがって， $\alpha_{u}$ が大きくなる 場合には，ばねが無限に分布されているとする弾性床上 のはりモデルは適用限界があり， $\alpha_{u}=1 / 5$ 程度で本算定 式は約 $10 \%$ 程度過小評価することになる. また，側径 間部については, $\mathrm{K}$ 橋の場合, $\beta l_{s}=2$ 程度となっており,

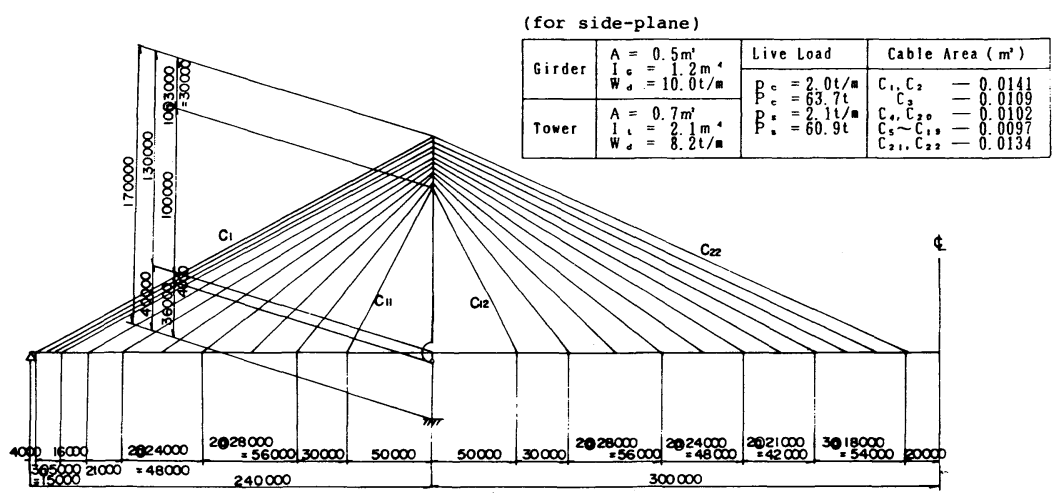

Fig. 11 Model $(240 \mathrm{~m}+600 \mathrm{~m}+240 \mathrm{~m})$ typeA. 


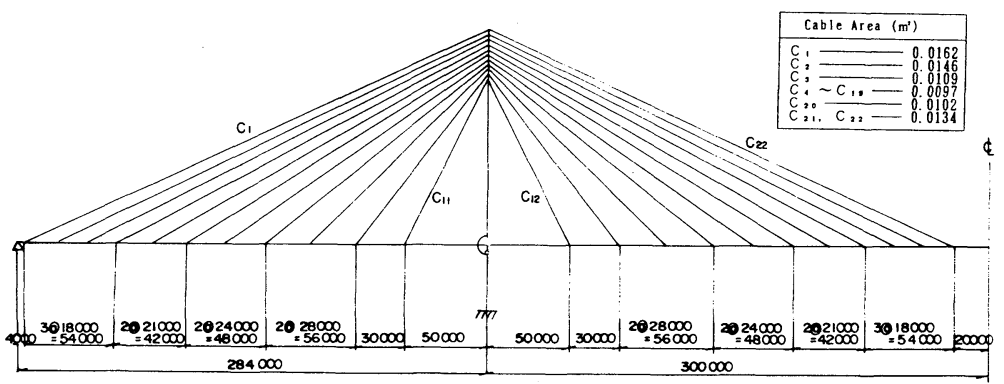

Fig. 12 Model $(284 \mathrm{~m}+600 \mathrm{~m}+284 \mathrm{~m})$ typeB.

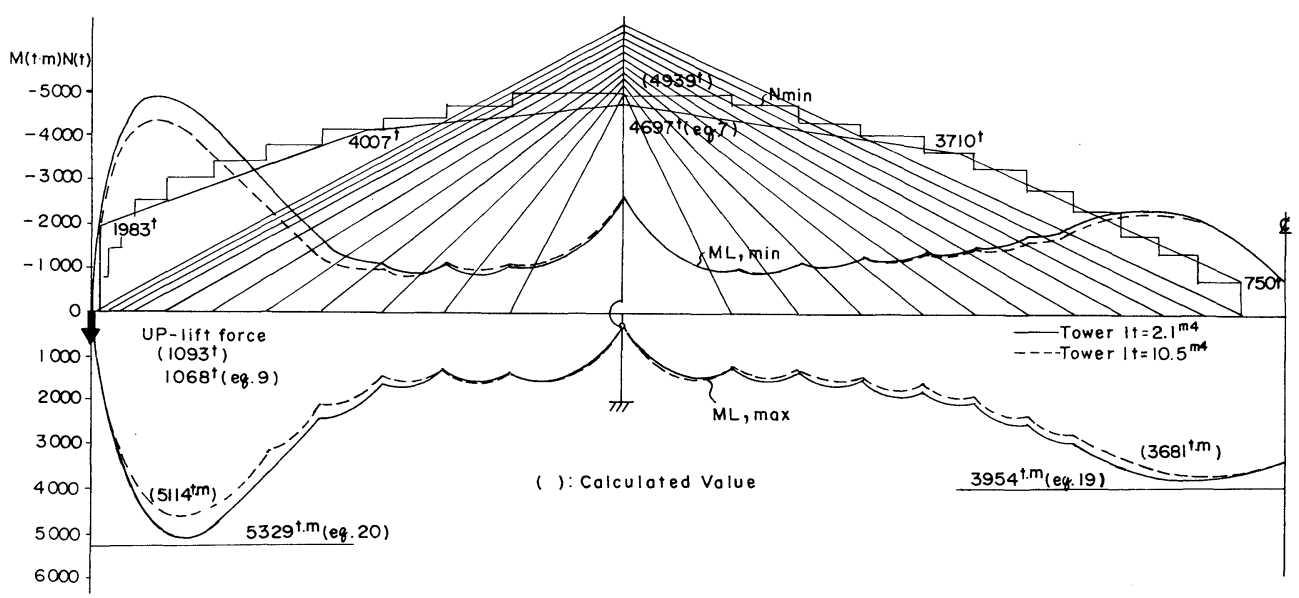

Fig. 13 Axial Force and Bending Moment of the Girder (TypeA).

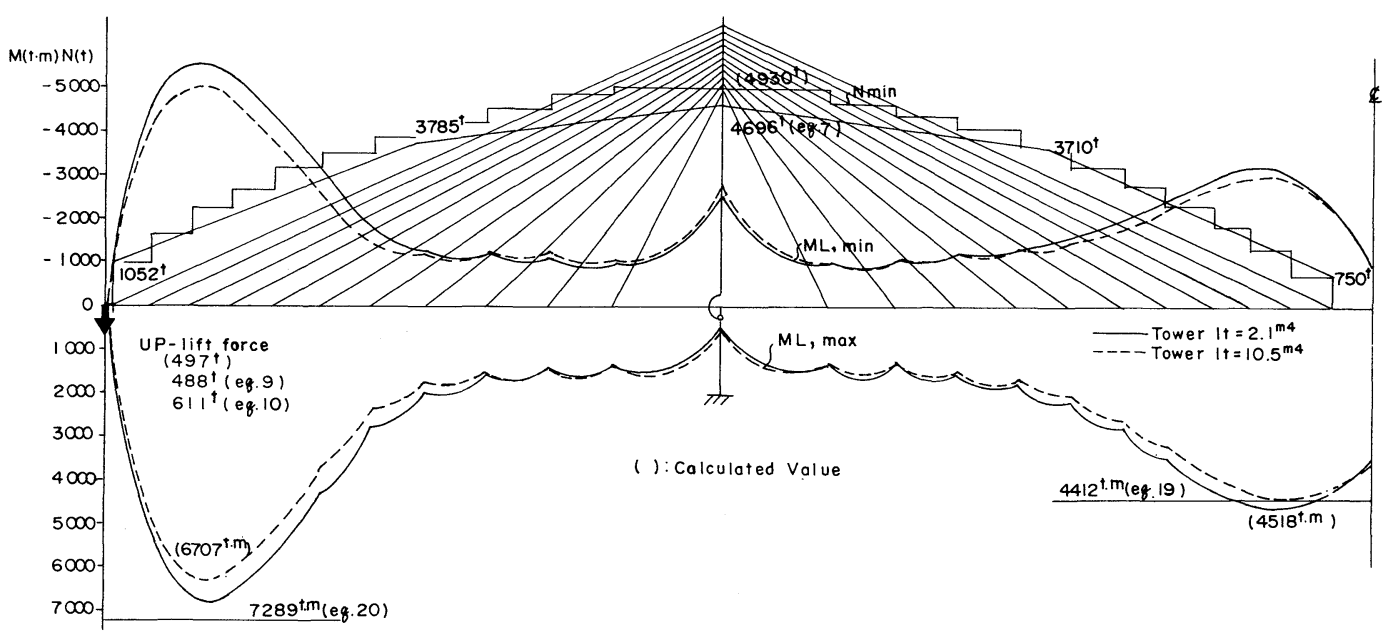

Fig. 14 Axial Force and Bending Moment of the Girder (TypeB).

無限弾性床上のはりモデルを考える限界 $\beta l>\pi$ よりか なり小さいため, 本算定式が危険側の評価をしていると 考えられる.ちなみに， $\mathrm{M}$ 橋の $\beta l_{s}$ は 3 程度であった.

以上， $\alpha_{u}$ がかなり大きくなる場合，また， $\beta l_{s}$ が $\pi$ よ りかなり小さくなる場合は, 本算定式は今後洗練させる
必要がある。

\section{（2）主塔軸力および曲げモーメント}

Fig. 15 に, 主塔軸力および曲げモーメントの比較結 果を示す. 主塔軸力については算定式, 計算結果ともに よい一致を示すことが確認できた。 なお，算定式では， 
桁下区間について，塔位置ケーブル間隔の半分に全荷重 を乗じたものを桁支点反力として，さらに塔自重が考慮 されている.

主塔曲げモーメントの算定式はかなり安全側の值を与 える. Type B で約 $7 \%$, Type A で約 $35 \%$ になって いる．これより，本算定式は支間長比 2 程度のケースが カバーできると考えられ，支間長比が大きくなるにつれ て安全側となる。

\section{（3）端支点上揚力}

Fig. 13, 14 に端支点上揚力の比較結果を示す. 算定式, 計算結果ともによい一致を示すことが確認できた.

\section{（4） ケーブル張力}

Type A のモデルについて，ケーブル張力の比較結果 を Fig. 16 に示す. 図中, ○印は計算結果, $\triangle$ 印は式 (31) より求めた值である．このとき，各ケーブルのばね定数 $k$ は次のようにして求めた。 まず，各ケーブルに $p L_{c D}$ の荷重を考える. 式 (34) の右辺第 1 項の $\alpha$ 值として, $p L_{c D}$ 分の荷重を考え, 中央径間で $\left(2 L_{c D} / l_{c}\right) \alpha$, 側径間 で $\left(L_{c D} / l_{s}\right) \alpha$ を採用する. また，式 (34) の右辺第 2 項の係数は, 集中荷重を無視したことから $\omega /(1+1.3 \omega)$ とする.さらに, $\tilde{\beta} \sigma_{a}=0.95 \times 64000=60800 \mathrm{t} / \mathrm{m}^{2}, E_{c}$ $=2 \times 10^{7} \mathrm{t} / \mathrm{m}^{2}$ と仮定する. $L_{\mathrm{A}}$ としては各ケーブルの長 さ， $h$ は塔の桁上高さとする.これより，たわみ $\delta を$ 求め, $k=p L_{c D} / \delta / L_{c D}$ と定義した.

側径間で集約されたケーブルおよび中央径間最上段 ケーブルを除いて，本算定式と計算結果は比較的よい一 致を示し，初期値として十分利用できると考える．中央 径間上段部 2 本のケーブルについては，計算値は算定式 の平均值程度と評価できる.平均值を図中のム印で示す.

側径間最上段ケーブル張力の推定は困難を伴う. 最上 段ケーブル張力は式 $(6)_{\mathrm{a}}$ で与えられているが, それ
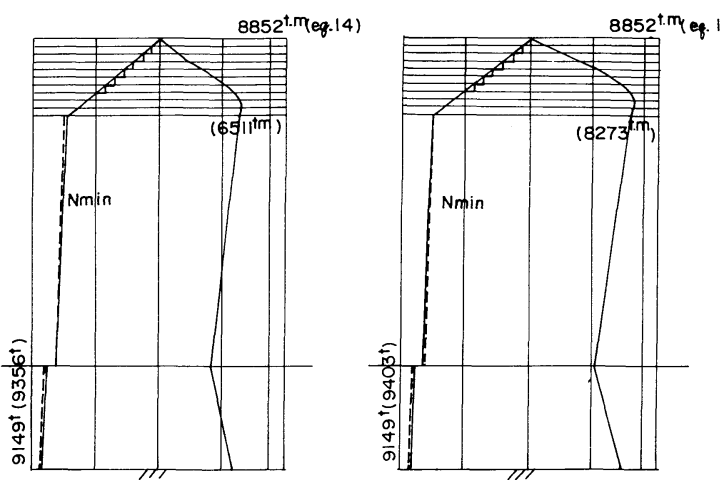

(a) Type $A$

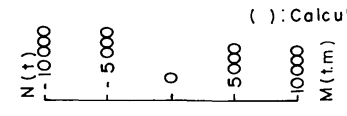

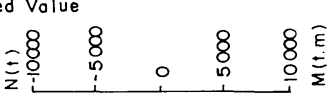

(b) Type B
Fig. 15 Axial Force and Bending Moment of the Tower.

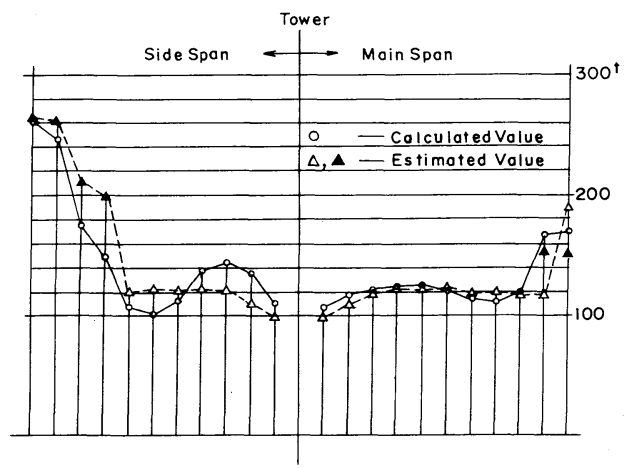

Fig. 16 Comparison of Cable Tension Forces.

によれば，張力は約 $790 \mathrm{t}$ となり，1 本のケーブルで受 けもつと考えれば過大に安全側となる.そこで, 式 ( 6 ) a で得られる張力を, 集約した 4 本のケーブルで, かつ断面積比に応じて受けもつと考える．さらに側径間 部の活荷重強度も均等に受けもつとして計算した結果を 図中のム印で示す．多少誤差は生じるものの初期値設定 には利用できると考える.

\section{8. まとめ}

3 径間連続マルチケーブル斜張橋を対象に, 部材断面 力の算定法ならびに主桁曲げ剛度とケーブル伸び剛度の 比について検討を加え，基本設計上有益之考えられる資 料を提示した. 本文の考察で得られた結果を要約すると 以下のとおりである.

（1）主桁および主塔の軸力算定式ならびに分布状態 を考慮した図を与えた。数值計算結果から，本算定式が 実用上十分な精度を有していることが確認できた。

（2）主塔の曲げモーメントについては, 支間長比= 2 程度に対して十分な精度を有していると考えられる が，支間長比が大きくなるにつれて，算定式は安全側に なる。

（3）従来まで推定が困難とされていた活荷重による 主析曲げモーメントについて，BEFアナロジーに基づ く考察から，精度のよい算定式を与えた．本式を適用す る場合，支間中央部のケーブルで吊られていない区間長 と中央支間長の比 $\alpha_{u}$ が大きくなると危険側の評価を し， $\alpha_{u}=1 / 5$ で $10 \%$ 程度となる. 中央径間部では，ほ とんどの橋梁が $\beta l_{c}>\pi$ (Fig. 8 参照) のため, 上述の問 題を除けば無限弾性床上のはりモデルの適用は妥当と考 えられるが，側径間長が短くなり， $\beta l_{s}$ が $\pi$ よりかなり 小さくなる場合には適用に問題がある.

（4）斜張橋のケーブルは全荷重強度を受けもつもの として設計すれば，ほぼその剛度が決定できるが，主桁 の曲げモーメントは不静定構造物の特性として, 曲げ剛 
度次第で大きく変動する，そこで, 主桁の断面二次モ一 メントの変化に伴う曲げモーメントの変動を精度よく推 定する図を与えた。

（5）BEF アナロジーに基づき，主妳の曲げ剛度と ケーブルの伸び剛度の比に関する新しいパラメーターを 定義した.このパラメーターにより, 主桁曲げモーメン 卜ならびにケーブル張力が精度よく推定できることか ら，物理的意味は従来より明確になっていると考える。 中央径間中央に着目した $\beta$ 値の実績調査から，主枌断 面二次モーメントの選定法を示した。そこでは，支間 $600 \mathrm{~m}$ の斜張橋の解析を通して, 支間 $400 \mathrm{~m} \sim 600 \mathrm{~m}$ の 長大斜張橋の主桁断面二次モーメントの選定法が示され ており,今後の長大橋の基本計画に役立つもの之考える.

（6）従来，明確にされていなかった集中荷重による ケーブル張力を含めて,ケーブル張力の算定式を与えた. 数値計算結果から実用上十分な精度を有していることが 確認できた。また，中央径間最上段部および側径間最上 段部ケーブルの張力算定法についても一提案を行った.

以上，マルチケーブル斜張橋の基本計画上有益と考え られる部材断面力の精度よい算定式を与えた。 また，こ れらの結果は電算解析結果の照査にも十分利用できると 考える. なお，長大斜張橋の設計に当たっては，部材の 安定性に関する照查には十分な注意が必要であり，主桁
断面二次モーメントの選定法と関連づけて，今後の重要 な検討課題であると考える。

謝辞：本文をまとめるに当たり，貴重な資料を提 供していただいた大阪市土木局橋梁課橋梁係長 石岡英 男氏および日本道路公団東京湾横断道路調查室室長代理 川人達男氏（前名港西大橋工事事務所構造工事長）に厚 く感謝の意を表します。

\section{参 考 文 献}

1) Gimsing, N. J. : Cable Supported Bridge, Concept and Design, John Willy \& Sons, 1983.

2）土木学会編：構造力学公式集，技報堂，1974 年.

3）日本道路協会 : 道路橋示方書 - 同解説, II 鋼橋編, 丸善, 1980 年.

4）長井正嗣・赤尾 宏・佐野信一郎・井澤 衞: 3 径間連 続マルチケーブル斜張橋の基本形状決定に関する一考察, 土木学会論文集, 第 362 号, 1985 年 10 月.

5）前田幸雄・林 正・井本賀章 : 斜張橋の剛性による静 力学的特性に関する一考察, 土木学会論文報告集, 第 199 号, 1972 年 3 月.

6）建設コンサルタンツ協会近畿支部：斜張橋の実績調査報 告, 1982 年 5 月.

(1985.5.27 - 受付) 